\title{
Follistatin serum concentrations during full-term labour in women - significant differences between spontaneous and induced labour
}

\author{
K Rae, K Hollebone ${ }^{1}$, V Chetty ${ }^{2}$, D Clausen ${ }^{2}$ and J McFarlane
}

School of Biological, Biomedical and Molecular Sciences, University of New England, Armidale, New South Wales 2351, Australia, ${ }^{1}$ Department of Obstetrics, Tamworth Base Hospital, Johnston Street, Tamworth, New South Wales 2340, Australia and ${ }^{2}$ Pathology New England, Johnston Street, Tamworth, New South Wales 2340, Australia

Correspondence should be addressed to K Rae; Email: kym.rae@hnehealth.nsw.gov.au

K Rae is now at University Department of Rural Health, University of Newcastle, Locked Bag 9783, New England Mail Sorting Centre, Tamworth, New South Wales 2348, Australia

\begin{abstract}
Follistatin has been isolated from human placenta and has been identified in human foetal membranes and fluids. Serum follistatin levels in women rise during pregnancy particularly near term. In this study, we examined the effect of induction and stage of labour on maternal plasma concentrations of follistatin. Women who gave birth after a normal pregnancy were retrospectively divided into three groups: those who went in labour spontaneously $(n=33)$, needed induction by amniotomy and IV oxytocin $(n=18)$ or underwent planned caesarean section $(n=10)$. Serum was collected at 38-40 weeks of gestation, periodically through labour with a vaginal examination and once within $36 \mathrm{~h}$ postpartum and assayed for oestradiol, progesterone, prolactin and C-reactive protein. Follistatin was measured using a rabbit antiserum $(\# 204)$ raised against purified $35 \mathrm{kDa}$ bovine follistatin. Human recombinant follistatin was used as both standard and tracer. Concentrations of follistatin at 38-40 weeks of gestation were significantly different between groups. Those who had a spontaneous labour had concentrations higher than those who were induced. Similarly, those who were induced had concentrations higher than those who underwent a caesarean. In the spontaneous group, follistatin rose during labour, peaking at $57.9 \pm 5.48 \mathrm{ng} / \mathrm{ml}$ at $>3 \mathrm{~cm}$ of cervical dilation, and after delivery follistatin decreased to $26.16 \pm 3.4 \mathrm{ng} / \mathrm{ml}$ at $24 \mathrm{~h}$ post-delivery. In induced patients follistatin continued increasing to peak following delivery at $26.9 \pm 3.0 \mathrm{ng} / \mathrm{ml}$ and decreased at $>3 \mathrm{~h}$ post-delivery. Follistatin concentrations in caesarean section patients at $24 \mathrm{~h}$ post-surgery $(18.53 \pm 3.74 \mathrm{ng} / \mathrm{ml})$ were not different from that before the surgery and were comparable with the other two groups. Follistatin is clearly implicated in the onset of labour; however, further studies with a larger cohort of women are necessary to determine the nature of its role.

Reproduction (2007) 134 705-711
\end{abstract}

\section{Introduction}

The monomeric activin-binding protein follistatin, isolated in 1987, on the basis of its role in the suppression of follicle stimulating hormone (Robertson et al. 1987, Ueno et al. 1987), has now been implicated in a multitude of physiological systems in human females and males, but in the latter it usually remains unchanged. Follistatin is widely recognised for its ability to modulate the actions of activin, a member of the transforming growth factor $\beta$ superfamily. There have been up to six isoforms isolated, formed from alternate splicing sites and a variety of glycolysation and post-translational proteolytic cleavage, with the splice variants being follistatin-315 (FS315) and follistatin-288 (FS288; Sugino et al. 1993). Follistatin preferentially binds activin with high affinity, with some isoforms having the ability to interact with heparan sulphate proteoglycans on cell surface membranes (Nakamura et al. 1991).

Follistatin has been implicated in the female reproductive axis, pregnancy (reviewed by Phillips \& de Kretser 1998) and embryonic development (Tashiro et al. 1991, Mummery \& van den Eijnden-van Raaij 1993, Tuuri et al. 1994). The reported concentrations of total follistatin through pregnancy have been somewhat inconsistent between assays and groups. Previous cross-sectional studies of maternal serum in pregnancy show that activin concentrations increase in women in the third trimester, with activin A being the predominant isoform in all pregnant women (Draper et al. 1997, Petraglia 1997, Schneider-Kolsky et al. 2000, Wang et al. 2002).

Woodruff et al. (1997) reported that while total follistatin concentrations increased in late pregnancy, 
in all women there were no significant increases in the small percentages of free follistatin. Khoury et al. (1995) also reported increases in total follistatin across pregnancy but did not clearly define gestational period (Khoury et al. 1995). In studies by Evans et al. (1998) and O'Connor et al. (1999), the results for total follistatin show a similar trend of increasing follistatin with gestational progression. The increased concentration of follistatin observed in the final trimester of gestation has led to interest in follistatin as a marker for the onset of parturition. However, the Schnieder-Kolsky et al. (2000) study to determine the involvement of both activin and total follistatin (FS288) across parturition in patients undergoing spontaneous labour, induction of labour and caesarean section delivery showed no significant changes in either protein.

Both follistatin and activin have been implicated in inflammatory pathways involved in wound repair, systemic inflammation and illnesses such as meningitis in both males and females (Klein et al. 1996, Jones et al. 2000, Keelan et al. 2000, Wankell et al. 2003). Such inflammatory pathways can initiate the acute phase response, involving the acute phase marker $\mathrm{C}$-reactive protein (CRP) and/or stress response which can stimulate the production of cortisol from the adrenals.

Follistatin's activin regulatory role is well established, and there is evidence suggesting that this partnership interacts with prolactin (PRL) during decidualisation (Jones et al. 2002). Early studies on cultured stromal cells indicate that activin promotes decidualisation (Jones et al. 2002) with stromal cells producing both activin receptor and activin $\beta_{\mathrm{A}}$ subunits in high concentrations with onset of decidualisation. One of the earliest markers of decidualisation is production of $\mathrm{PRL}$, by decidualised endometrial stromal cells as well as the pituitary (Thrailkill et al. 1989, Frank et al. 1995). Jones et al. (2002) established in in vitro cultures that decidualisation had occurred through the increased levels of PRL; however, the production of PRL ceased upon administration with follistatin.

Due to the inconsistencies in the current published data (likely to be due to measurement of differing follistatin isoforms), we measured total follistatin (FS288) in blood samples from labouring and non-labouring patients using an antibody and an assay (O'Connor et al. 1999) distinct from that used by Schneider-Kolsky et al. (2000) study. This research has endeavoured to establish any links between follistatin and the acute phase response, using wellestablished markers of this pathway CRP and the stress marker cortisol. Additionally, this study reviewed the routine hormones of pregnancy, oestradiol and progesterone, to establish any links with the actions of follistatin and as a serological measure of placental expulsion.

\section{Results}

\section{Oestradiol and progesterone}

Results from the traditional gestational hormones, oestradiol and progesterone, show the expected pattern of concentration changes across the sample period from antenatal through $24 \mathrm{~h}$ post-delivery (data not shown), i.e. concentrations peak in early labour with respect to the antenatal period that fall rapidly by the early postpartum period when the placenta is removed.

Oestradiol and progesterone show that in early labour, spontaneous onset patients have higher concentrations $(P<0.05)$ of both of these hormones when compared with the induced patient group (oestradiol: $91.4 \mathrm{nmol} / \mathrm{I} \pm 15.5$ and $65.1 \mathrm{nmol} / \mathrm{l} \pm 8.78$ respectively; and progesterone: $314.5 \mathrm{nmol} / \mathrm{l} \pm 32.0$ and $224.8 \mathrm{nmol} / \mathrm{l} \pm 32.9$ respectively). As labour progressed, there was a trend to maintaining an increased concentration of both hormones in the spontaneous patients; however, it was not deemed significant from the induced patient group.

\section{Cortisol}

In both vaginal delivery groups, cortisol (Fig. 1) rises from the antenatal period across labour to peak at the early postpartum sample (spontaneous Ante: $663.9 \mathrm{nmol} / \mathrm{I} \pm$ 52.6, Lab2: $1108.1 \mathrm{nmol} / \mathrm{l} \pm 89.9$, Post1: $1691.6 \mathrm{nmol} / \mathrm{I} \pm$ 251.2; induced Ante $421.1 \mathrm{nmol} / \mathrm{I} \pm 43.6$, Lab2: $987.9 \mathrm{nmol} / \mathrm{I} \pm 194.3$, Post1: $1424.21 \mathrm{nmol} / \mathrm{I} \pm 154.21$ ). In the spontaneous labour patients, these results showed a significant pattern of increasing concentrations $(P<0.02)$. Whilst induced patients showed a similar pattern, the antenatal samples in this group were significantly less than all subsequent samples $(P<0.03)$.

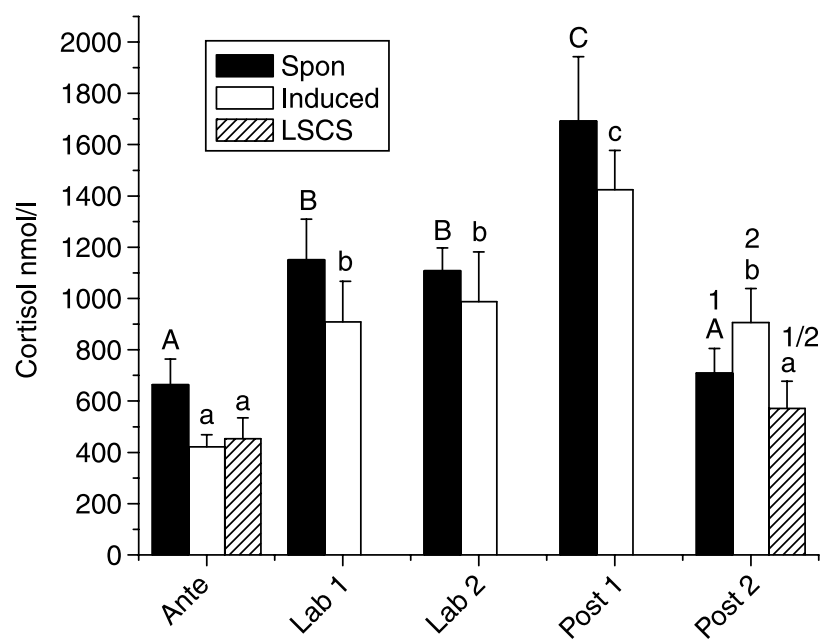

Figure 1 Profile of cortisol across the antenatal period, Lab1 $(0-3 \mathrm{~cm}$ vaginal dilation) Lab2 ( $>3 \mathrm{~cm}$ dilation), Post1 ( $0-3$ h post delivery) and Post2 (3-24 h post delivery). Significant differences within each group (Spon, Induced and LSCS) are indicated with letters. Significant differences between groups are indicated numerically. 
In the late postpartum sample period, a decrease in the spontaneous and induced patient groups is seen. Interestingly, in late postpartum, induced patients have the highest concentration $(906.7 \mathrm{nmol} / \mathrm{l} \pm 132.4)$ when compared with spontaneous labour and caesarian section (LSCS) deliveries $(708.5 \mathrm{nmol} / \mathrm{I} \pm 96.1$ and $571.7 \mathrm{nmol} / \mathrm{I} \pm 106.4$ respectively).

\section{Prolactin}

As shown in Fig. 2, in the spontaneous labour patients, there is a trend to increasing PRL between the antenatal period and the final postpartum sample $(2773.6 \pm 242.3 \mu \mathrm{lU} / \mathrm{ml}$ to $4823.9 \pm 581.2 \mu \mathrm{lU} / \mathrm{ml})$. Induced patients show PRL reaching its significant peak $(P<0.004)$ at late labour $(5449.40 \pm 890.71 \mu \mathrm{lU} / \mathrm{ml})$ and then dropping significantly to reach to early labour levels in the first postpartum period $(3906.89 \pm 806.32 \mu \mathrm{lU} / \mathrm{ml})$.

\section{Follistatin}

Follistatin concentration changes in maternal serum over time are profiled in Fig. 3. In the spontaneous labour patients, follistatin showed significant differences between antenatal, early labour, late labour and early postpartum samples, whilst the induced patients showed significant differences between labouring samples and the early postpartum sample $(P<0.01)$.

Of great interest are the differences seen between these two patient groups within both labouring samples and early postpartum samples. In early labour, spontaneous patients have significantly higher concentrations of follistatin $(P<0.01)$ than induced patients $(23.4 \mathrm{ng} / \mathrm{ml} \pm 1.84$ to

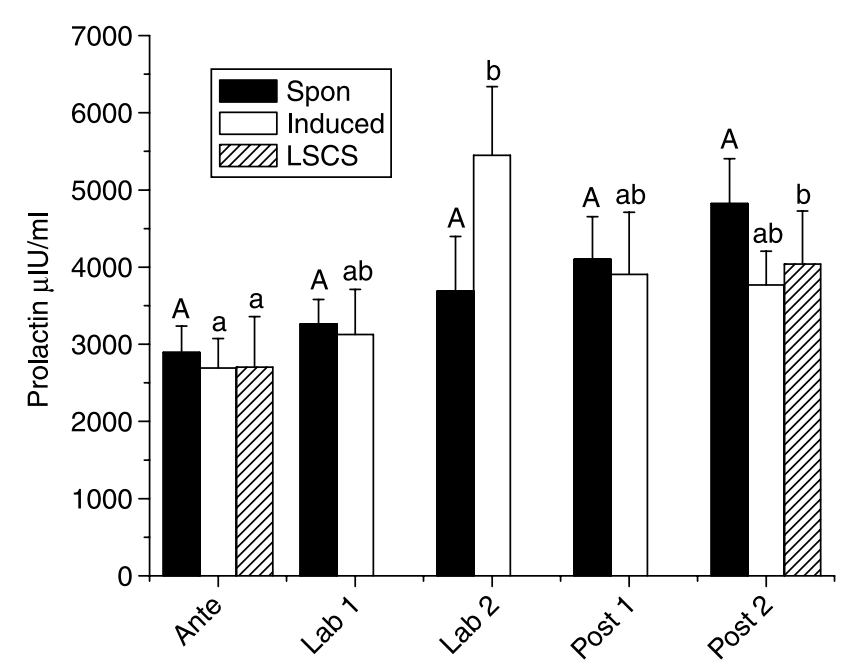

Figure 2 Profile of prolactin across the antenatal period, Lab1 $(0-3 \mathrm{~cm}$ vaginal dilation) Lab2 ( $>3 \mathrm{~cm}$ dilation), Post1 ( $0-3 \mathrm{~h}$ post delivery) and Post2 (3-24 h post delivery). Significant differences within each group (Spon, Induced and LSCS) are indicated with letters. Significant differences between groups are indicated numerically.

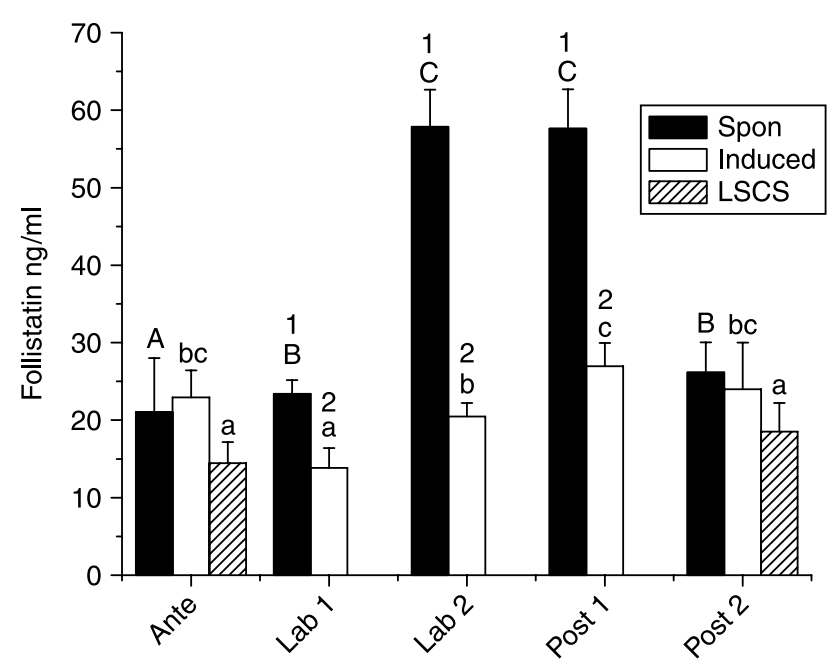

Figure 3 Profile of follistatin across the antenatal period, Lab1 $(0-3 \mathrm{~cm}$ vaginal dilation) Lab2 ( $>3 \mathrm{~cm}$ dilation), Post1 ( $0-3 \mathrm{~h}$ post delivery) and Post2 (3-24 h post delivery). Significant differences within each group (Spon, Induced and LSCS) are indicated with letters. Significant differences between groups are indicated numerically.

$13.9 \mathrm{ng} / \mathrm{ml} \pm 2.54$ respectively), whilst in late labour there is a twofold difference which peaks in the spontaneous group $(P<0.0004)$. When the two groups are compared at late labour, follistatin concentrations are $57.9 \mathrm{ng} / \mathrm{ml} \pm 5.48$ and $20.5 \mathrm{ng} / \mathrm{ml} \pm 1.73$ respectively. Follistatin remains significantly elevated $(P<0.0003)$ in spontaneous labour patients in the early postpartum $(57.6 \mathrm{ng} / \mathrm{ml}+5.1)$ when compared with induced patients $(26.9 \mathrm{ng} / \mathrm{ml}+3.0)$. The induced patients show follistatin continues to rise from labour, into the early postpartum period and reaches its peak concentration here $(26.9 \mathrm{ng} / \mathrm{ml} \pm 3.0$ to $20.5 \mathrm{ng} / \mathrm{ml} \pm 1.73$ in late labour). In the later postpartum period, we see follistatin concentrations in both patient groups decreasing.

\section{C-reactive protein}

As seen in Fig. 4, CRP concentrations in all patient groups remain relatively steady from antenatal period and across labour into the early postpartum period. However, in the late postpartum period, we see a four- to fivefold increase in CRP in all patients. Spontaneous patients increase significantly $(P<0.0006)$ from early postpartum $13.4 \mathrm{mg} / \mathrm{l} \pm 3.96$ to $43.7 \mathrm{mg} / \mathrm{l} \pm 12.0$ in the later postpartum sample. Induced and LSCS patients increase from $11.0 \mathrm{mg} / \mathrm{l} \pm 2.61$ and $4.92 \mathrm{mg} / \mathrm{l}$ to $44.1 \mathrm{mg} / \mathrm{l} \pm 9.69$ and $55.2 \mathrm{mg} / \mathrm{l} \pm 12.2$ respectively $(P<0.0003)$.

\section{Discussion}

This current study has shown that there are clear indications for the involvement of follistatin in the parturition process. Follistatin concentrations were 


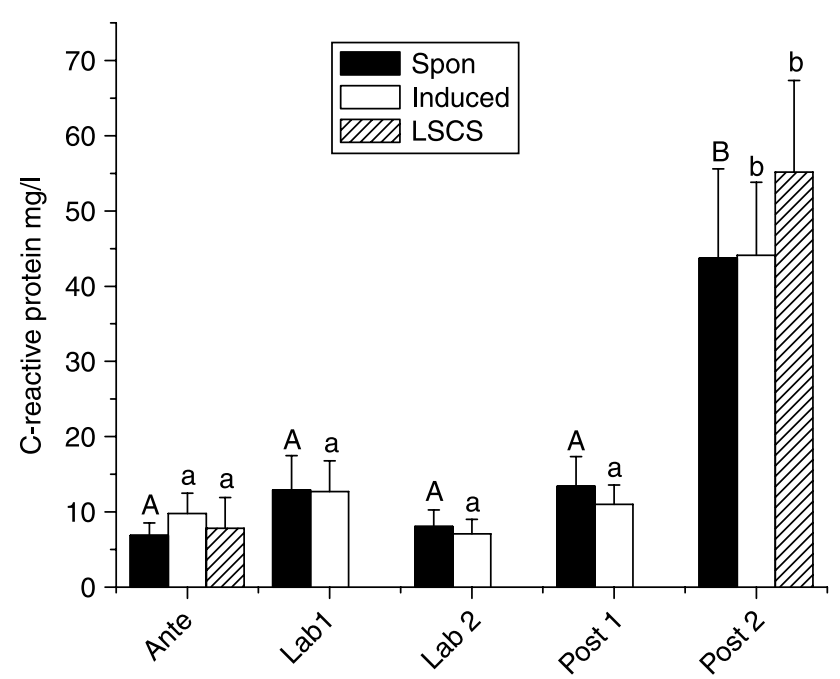

Figure 4 Profile of C-reactive protein across the antenatal period, Lab1 (0-3 cm vaginal dilation) Lab2 ( $>3 \mathrm{~cm}$ dilation), Post1 $(0-3 \mathrm{~h}$ post delivery) and Post2 (3-24 h post delivery). Significant differences within each group (Spon, Induced and LSCS) are indicated with letters. Significant differences between groups are indicated numerically.

significantly higher in labouring samples in the spontaneously labouring patient when compared with the induced patient. Concentrations were higher in spontaneous patients with $<3 \mathrm{~cm}$ cervical dilation and follistatin concentrations in the spontaneously labouring patient were greater than twofold those measured in induced patients in late labour when dilation $>3 \mathrm{~cm}$.

The Schneider-Kolsky et al. (2000) assessment of follistatin and activin across spontaneous parturition in 36 women correlated results with cervical dilation, and no changes in follistatin concentrations were shown. In the same study, nine women undergoing inductions had serum collected at 60-min intervals from the time of the amniotomy to delivery and they also showed no significant changes in either follistatin or activin concentrations. A number of women in this study had pre-existing medical conditions such as gestational diabetes and non-proteinuric hypertension (SchneiderKolsky et al. 2000). Previous studies have shown that follistatin concentrations may alter with inflammatory conditions, creating the possibility that concentrations measured by Schneider-Kolsky et al. were influenced by pre-existing conditions in the patients (Schneider-Kolsky et al. 2000).

The multiplicity of isoforms of follistatin, the high affinity for activin and its $85 \%$ homology between species have made the development of accurate assays for follistatin a difficult task (Sugino et al. 1993, Evans et al. 1998). The Schneider-Kolsky et al. (2000) study utilised a follistatin assay that was different from the one used in the present study. The antibody used by Schneider-Kolsky et al. (2000) is a monoclonal mouse antibody raised against human recombinant rhFS288, whilst the O'Connor et al. (1999) assay, as utilised in this study, uses a polyclonal rabbit antibody raised against purified $35 \mathrm{kDa}$ bovine follistatin. As indicated by the variability of results in previous studies, the different antibodies are probably measuring differing follistatin isoforms. When considering all follistatin results, including those in the present study, one must consider the multiplicity of follistatin isoforms and the potential diversity of actions of each of these isoforms.

The lack of agreed standards for measuring follistatin and the availability of ten different assays makes the interpretation across studies difficult. At least two groups indicate that their assay determines the levels of unbound follistatin (Wang et al. 1996, McConnell et al. 1998), whilst the other assays measure total (bound and unbound) follistatin (Sugawara et al. 1990, Klein et al. 1991, Gilfillan \& Robertson 1994, Khoury et al. 1995, Wakatsuki et al. 1996, Evans et al. 1998, McConnell et al. 1998, de Kretser et al. 1999, O'Connor et al. 1999).

When considering the diverse and often contradictory data on follistatin, one must consider the multiple isoforms of follistatin and the potential that they may have different physiological functions. The strongest evidence for differing functions comes from the different distribution of isoforms FS3155 and FS288 between tissues, and the different interactions with cellular membranes (Sidis et al. 2006). Recent work by Sidis et al. (2006) showed that follistatin isoforms differentially regulated testicular tumour cells, with FS288 suppressing and FS315 enhancing the activin-driven proliferation of these cells, so that it remains possible for follistatin isoforms to have different modes of action in pregnancy and parturition (Sidis et al. 2006). Despite evidence in other studies to the contrary, it is clear from this present study that follistatin does have a role to play in the onset and parturition process, even though we are probably measuring a different isoform from other across-labour studies. Data from Schneider-Kolsky et al. (2000) showing no changes to follistatin in labour, along with this study's finding, suggest that there are follistatin isoforms that are differentially regulated across the parturition of women.

This study has shown that oestradiol and progesterone concentrations drop below antenatal concentrations following delivery, confirming the placenta as the major source of these hormones. Studies have shown high concentrations of follistatin in the placenta, amnion and choriodecidua, implying that these tissues are potential sources for follistatin in maternal serum (Kaiser et al. 1990, Mercado et al. 1993, Yokoyama et al. 1995, Petraglia 1997, Keelan et al. 1999). In this study, follistatin concentrations decreased at the same time as both oestradiol and progesterone, although they failed to reach antenatal levels until the late postpartum period. Kogure et al. (1996) indicated that the half-life for follistatin is $\sim 4 \mathrm{~min}$, hence if the placenta was the source of the follistatin in maternal serum levels should 
return to antenatal concentrations or below within the first postpartum period ( $<3 \mathrm{~h}$ from delivery; Kogure et al. 1996). These current results suggest that follistatin increases seen in labour are from a different source or in addition to the placental follistatin. Phillips \& de Kretser (1998) demonstrated that follistatin mRNA and protein are widely distributed throughout the body, so that there are many possible sources for the increases seen in maternal serum, such as the vascular endothelial cells (Phillips \& de Kretser 1998).

Work by Sidis et al. (2006) indicated that the biological activity of follistatin is due to its ability to interact at the cell surface through heparan sulphate proteoglycans (Sidis et al. 2006). Studies on the myometrium have shown that whilst other myometrial proteoglycans decrease, heparan sulphate proteoglycans increase by $46 \%$ in active labour (Hjelm et al. 2002) which can potentially increase the interactions with follistatin. This period coincided with the highest concentrations of follistatin measured in this study. This study has showed follistatin concentrations to increase through parturition (Fig. 3), peaking with established labour $>3 \mathrm{~cm}$ dilation. It also shows that follistatin is elevated in women who are in spontaneous labour when compared with those undergoing an induction. Of particular interest, in spontaneous labour follistatin is significantly higher than antenatal levels even at a minimal cervical dilation $(0-3 \mathrm{~cm})$, indicating that follistatin is rising whilst the pre-labour stage of cervical ripening occurs. Although the study by Schneider-Kolsky et al. (2001) showed neither activin $\beta_{\mathrm{A}}$ subunits nor any of the three activin receptors were immunolocalised to the myometrial smooth muscle cells in active labour, perhaps the elevations noted in this study are due to the actions of the follistatin/activin complex or those of follistatin individually. The follistatin/activin complex or follistatin individually may be acting in concert with the increasing number of uterine myometrial heparan proteoglycans through labour in uterine remodelling essential for birth.

Studies on stress have linked PRL and cortisol release in the physiological stress response (Armario et al. 1996, Richter et al. 1996). Whilst the current study did not show these links in the data (Figs 1 and 2), perhaps in a larger study, when samples could be analysed with respect to labour length, we may find such correlations. Knowing that PRL is influenced by activin, stress, cortisol, feeding status, etc., it seems that complete understanding of roles of PRL at parturition is multifactorial, and therefore a much larger patient cohort and rigorous sampling protocols are necessary to tease out its influence, if any, on parturition.

When reviewing follistatin results along with the stress marker, cortisol, and the acute phase protein, CRP (Figs 3 and 4), it can be observed that follistatin concentration increases in early labour in the spontaneous onset patients, well before either of these proteins. This suggests that follistatin is increasing due to stimuli other than that of stress or the acute phase response. While follistatin has been implicated in the acute phase response, this study clearly shows that the acute phase response triggered postpartum is distinct from that of follistatin increases seen during spontaneous labour. Perhaps the increases in follistatin that this study documents in early labour are the trigger for the adrenal glands to release glucocorticoids (Vanttinen et al. 2002) that then initiate or propagate the release of the acute phase response proteins from the hepatocytes in the liver to assist in the postpartum 'mop up' and uterine remodelling. The results showed follistatin concentrations remain elevated above antenatal concentrations in the postpartum period, suggesting that the placenta is not the major source of the follistatin seen in maternal serum.

Whilst this study has shown that follistatin concentrations increase significantly across labour, suggesting that it is involved with the spontaneous onset of parturition, there are still many aspects that need to be considered for further research. More frequent samples late in gestation would help establish these initial findings that follistatin is involved in the cervical ripening stage of parturition prior to active labour as well as a longer period of sampling post partum. We have previously reported that follistatin in the sheep rises and reaches maximal levels in the 36-48 $\mathrm{h}$ following parturition; therefore, a longer sampling period would be valuable to assess this in women (Rae et al. 2003).

Overall, this study has shown follistatin is clearly implicated in the spontaneous onset of labour in women. Further research is required to determine the exact role it plays during parturition.

\section{Materials and Methods}

\section{Experimental subjects}

Obstetric patients of the Tamworth Base Hospital in the New England Area Health Service were recruited into the study. Patients who suffered any pre-existing conditions, e.g. gestational diabetes, were excluded from the study. Any patients who had pre-labour membrane rupture or those who needed emergency or surgical intervention in labour were also excluded. Patients who suffered any adverse birth outcome were also excluded from the study. All women recruited to the study were in good health at the time of recruitment.

The mean age of women used in the study was 27.8 years (range of 18.8-42.7 years). The gestation of the women was calculated from a definite last menstrual period date or by paediatric judgment post-delivery using the well-established Dubowitz scoring system (Dubowitz \& Dubowitz 1977, Bhagwat et al. 1990, Egewarth et al. 2002). The average gestation of women in the study at term is 39.1 weeks with a range of 36-44 weeks. Using a patient cohort of 61 women who delivered by the end of the study, patients were separated according to whether delivery was a planned caesarean section or from spontaneous or induced onset of labour. Women who 
failed to go into spontaneous labour by 40 weeks plus 10 days were induced. Inductions were performed using amniotomy and IV oxytocin (syntocin) administered until the delivery. The characteristics of each of these groups are shown in Table 1.

This study was approved by the New England Area Health Service Clinical Research Group and Ethics Committee, and the University of New England Ethics Committee.

\section{Sample collection}

Venous blood samples were collected into $5 \mathrm{ml}$ vacuette $Z$ serum separator clot activator tubes (Greiner, St Gallen, Switzerland). These samples were centrifuged at $2683 \mathrm{~g}$ (4000 r.p.m.) for $10 \mathrm{~min}$ and immediately frozen at $-15^{\circ} \mathrm{C}$ and stored until assayed. Blood samples collected from patients have been grouped according to: antenatal (Ante); early labour, $<3 \mathrm{~cm}$ vaginal dilation (Lab1); late labour $>3 \mathrm{~cm}$ vaginal dilation (Lab2); early postpartum, $0-3 \mathrm{~h}$ post-delivery (Post1) and late postpartum, $>3 \mathrm{~h}$ and $<36 \mathrm{~h}$ post-delivery (Post2).

\section{Assays}

Samples were analysed for oestradiol, progesterone, cortisol and PRL using the automated clinical analyzer Access2 (Beckman-Coulter Australia Pty Ltd, Gladesville, NSW, Australia). CRP was analysed using the automated clinical analyzer Synchron (Beckman-Coulter Australia Pty Ltd).

Total follistatin was determined in plasma using a RIA as previously described by O'Connor et al. (1999). Briefly, the assay used a rabbit antiserum (\#204) raised against purified $35 \mathrm{kDa}$ bovine follistatin. A human recombinant follistatin (FS288) was used as both standard and tracer. The dissociation reagents were modified to $10 \%$ Triton X-100, 3\% sodium deoxycholate and $0.5 \%$ SDS. Cross-reactivity with inhibin and activin was $<0.5 \%$. The detection limit was $0.25 \mathrm{ng} / \mathrm{ml}$ and the intra- and inter-assay coefficients of variation were 6 and $12 \%$ respectively.

\section{Data analysis}

The raw hormone concentration data were log transformed to normalise the data and equalise the variance. The data were then analysed by two-way ANOVA using the Student-Newman-Keuls post test to compare individual means. All the calculations were carried out using the general linear model procedure and repeated statement of the SAS computer package (SAS Institute Inc., Cary, NC, USA). The values were presented as mean \pm s.E.M. and were considered significant at $P<0.05$.

Table 1 Characteristics of patients using type of onset as criteria for inclusion.

\begin{tabular}{lccc}
\hline Characteristics & $\begin{array}{c}\text { Spontaneous } \\
\text { onset }\end{array}$ & $\begin{array}{c}\text { Induced } \\
\text { onset }\end{array}$ & $\begin{array}{c}\text { Caesarean } \\
\text { section }\end{array}$ \\
\hline No. of deliveries & 33 & 18 & 10 \\
Gestation (weeks; median) & 39.3 & 38.6 & 39.7 \\
Age (years; median) & 27.6 & 26.7 & 30.1 \\
Length of labour & 6.5 & 4.5 & 0.0 \\
$\quad$ (h; median) & & & \\
\hline
\end{tabular}

\section{Acknowledgements}

We would like to thank all of the midwives and obstetricians of Tamworth Base Hospital whose diligence and attention to detail with patient sampling made this study possible. The authors would like to thank Beckman-Coulter for their assistance with the purchase of reagents. Assistance from the staff of Pathology New England (Tamworth) was greatly appreciated at all stages of the project. Antibodies for follistatin (\#204) kindly donated by Prof. David de Kretser, Institute of Reproduction and Development, Monash University, Clayton, Victoria, Australia. The authors declare that there is no conflict of interest that would prejudice the impartiality of this scientific work.

\section{References}

Armario A, Marti O, Molina T, de Pablo J \& Valdes M 1996 Acute stress markers in humans: response of plasma glucose, cortisol and prolactin to two examinations differing in the anxiety they provoke. Psychoneuroendocrinology 21 17-24.

Bhagwat VA, Dahat HB \& Bapat NG 1990 Determination of gestational age of newborns - a comparative study. Indian Pediatrics 27 272-275.

Draper LB, Chong H, Wang E \& Woodruff TK 1997 The uterine myometrium is a target for increased levels of activin A during pregnancy. Endocrinology 138 3042-3046.

Dubowitz L \& Dubowitz V 1977 A Clinical Manual: Gestational Age of Newborns. Phillipines: Addison-Wesley Publishing Company Inc.

Egewarth C, Pires FD \& Guardiola A 2002 Assessment of gestational age of preterm newborn based on neurological examination, obstetric dating criteria and pediatrics criteria. Arquivos de Neuro-Psiquiatria 60 755-759.

Evans LW, Muttukrishna S \& Groome NP 1998 Development, validation and application of an ultra-sensitive two-site enzyme immunoassay for human follistatin. Journal of Endocrinology 156 275-282.

Frank GR, Brar AK, Jikihara H, Cedars MI \& Handwerger S 1995 Interleukin-1 beta and the endometrium: an inhibitor of stromal cell differentiation and possible autoregulator of decidualization in humans. Biology of Reproduction 52 184-191.

Gilfillan CP \& Robertson DM 1994 Development and validation of a radioimmunoassay for follistatin in human serum. Clinical Endocrinology 41 453-461.

Hjelm AM, Barchan K, Malmstrom A \& Ekman-Ordeberg GE 2002 Changes of the uterine proteoglycan distribution at term pregnancy and during labour. European Journal of Obstetrics, Gynecology and Reproductive Biology 100 146-151.

Jones KL, Brauman JN, Groome NP, de Kretser DM \& Phillips DJ 2000 Activin A release into the circulation is an early event in systemic inflammation and precedes the release of follistatin. Endocrinology 141 1905-1908.

Jones RL, Salamonsen LA \& Findlay JK 2002 Activin A promotes human endometrial stromal cell decidualization in vitro. Journal of Clinical Endocrinology and Metabolism 87 4001-4004.

Kaiser M, Gibori G \& Mayo KE 1990 The rat follistatin gene is highly expressed in decidual tissue. Endocrinology 126 2768-2770.

Keelan JA, Marvin KW, Sato TA, McCowan LM, Coleman M, Evans LW, Groome NP \& Mitchell MD 1999 Concentrations of activin A, inhibin A and follistatin in human amnion, choriodecidual and placental tissues at term and preterm. Journal of Endocrinology 163 99-106.

Keelan JA, Zhou RL, Evans LW, Groome NP \& Mitchell MD 2000 Regulation of activin A, inhibin A, and follistatin production in human amnion and choriodecidual explants by inflammatory mediators. Journal of the Society for Gynecologic Investigation 7 291-296.

Khoury RH, Wang QF, Crowley WF Jr, Hall JE, Schneyer AL, Toth T, Midgley AR Jr \& Sluss PM 1995 Serum follistatin levels in women: evidence against an endocrine function of ovarian follistatin. Journal of Clinical Endocrinology and Metabolism 80 1361-1368. 
Klein R, Robertson DM, Shukovski L, Findlay JK \& de Kretser DM 1991 The radioimmunoassay of follicle-stimulating hormone (FSH)-suppressing protein (FSP): stimulation of bovine granulosa cell FSP secretion by FSH. Endocrinology 128 1048-1056.

Klein R, Clarke IJ, Hedger MP \& Robertson DM 1996 Plasma follistatin concentrations increase following lipopolysaccharide administration in sheep. Clinical and Experimental Pharmacology and Physiology 23 754-755.

Kogure K, Zhang YQ, Kanzaki M, Omata W, Mine T \& Kojima I 1996 Intravenous administration of follistatin: delivery to the liver and effect on liver regeneration after partial hepatectomy. Hepatology 24 361-366.

de Kretser DM, Hedger MP \& Phillips DJ 1999 Activin A and follistatin: their role in the acute phase reaction and inflammation. Journal of Endocrinology 161 195-198.

McConnell DS, Wang Q, Sluss PM, Bolf N, Khoury RH, Schneyer AL, Midgley AR Jr, Reame NE, Crowley WF Jr \& Padmanabhan V 1998 A two-site chemiluminescent assay for activin-free follistatin reveals that most follistatin circulating in men and normal cycling women is in an activin-bound state. Journal of Clinical Endocrinology and Metabolism 83 851-858.

Mercado M, Shimasaki S, Ling N \& DePaolo L 1993 Effects of estrous cycle stage and pregnancy on follistatin gene expression and immunoreactivity in rat reproductive tissues: progesterone is implicated in regulating uterine gene expression. Endocrinology 132 1774-1781.

Mummery CL \& van den Eijnden-van Raaij AJ 1993 Type beta transforming growth factors and activins in differentiating embryonal carcinoma cells, embryonic stem cells and early embryonic development. International Journal of Developmental Biology 37 169-182.

Nakamura T, Sugino K, Titani K \& Sugino H 1991 Follistatin, an activinbinding protein, associates with heparan sulfate chains of proteoglycans on follicular granulosa cells. Journal of Biological Chemistry 266 19432-19437.

O'Connor AE, McFarlane JR, Hayward S, Yohkaichiya T, Groome NP \& de Kretser DM 1999 Serum activin A and follistatin concentrations during human pregnancy: a cross-sectional and longitudinal study. Human Reproduction 14 827-832.

Petraglia F 1997 Inhibin, activin and follistatin in the human placenta - a new family of regulatory proteins. Placenta 18 3-8.

Phillips DJ \& de Kretser DM 1998 Follistatin: a multifunctional regulatory protein. Frontiers in Neuroendocrinology 19 287-322.

Rae K, Xia Y, O'Shea T \& McFarlane JR 2003 Follistatin immunoreactive profiles across parturition in ewes using different assays. Proceedings of the 46th Annual Scientific Meeting for The Endocrine Society of Australia, Melbourne, Australia. Abstract 350, page 189.

Richter S, Schurmeyer T, Schedlowski M, Hadicke A, Tewes U, Schmidt R \& Wagner T 1996 Time kinetics of the endocrine response to acute psychological stress. Journal of Clinical Endocrinology and Metabolism 81 1956-1960.

Robertson DM, Klein R, de Vos FL, McLachlan RI, Wettenhall RE, Hearn MT, Burger HG \& de Kretser DM 1987 The isolation of polypeptides with FSH suppressing activity from bovine follicular fluid which are structurally different to inhibin. Biochemical and Biophysical Research Communications 149 744-749.

Schneider-Kolsky M, D'Antona D, Evans LW, Taylor N, O'Connor A, Groome NP, de Kretser D \& Wallace EM 2000 Maternal serum total activin A and follistatin in pregnancy and parturition. British Journal of Obstetrics and Gynaecology 107 995-1000.

Schneider-Kolsky M, Manuelpillai U, Gargett C \& Wallace EM 2001 Activin betaA-subunit and activin receptors in human myometrium at term and during labour. Bristish Journal of Obstetrics and Gynaecology 108 869-874.

Sidis Y, Mukherjee A, Keutmann H, Delbaere A, Sadatsuki M \& Schneyer A 2006 Biological activity of follistatin isoforms and follistatin-like-3 is dependent on differential cell surface binding and specificity for activin, myostatin, and bone morphogenetic proteins. Endocrinology 147 3586-3597.

Sugawara M, Depaolo L, Nakatani A, DiMarzo SJ \& Ling N 1990 Radioimmunoassay of follistatin: application for in vitro fertilization procedures. Journal of Clinical Endocrinology and Metabolism 71 1672-1674.

Sugino K, Kurosawa N, Nakamura T, Takio K, Shimasaki S, Ling N, Titani K \& Sugino H 1993 Molecular heterogeneity of follistatin, an activinbinding protein. Higher affinity of the carboxyl-terminal truncated forms for heparan sulfate proteoglycans on the ovarian granulosa cell. Journal of Biological Chemistry 268 15579-15587.

Tashiro K, Yamada R, Asano M, Hashimoto M, Muramatsu M \& Shiokawa K 1991 Expression of mRNA for activin-binding protein (follistatin) during early embryonic development of Xenopus laevis. Biochemical and Biophysical Research Communications 174 1022-1027.

Thrailkill KM, Golander A, Underwood LE, Richards RG \& Handwerger S 1989 Insulin stimulates the synthesis and release of prolactin from human decidual cells. Endocrinology 124 3010-3014.

Tuuri T, Eramaa M, Hilden K \& Ritvos O 1994 The tissue distribution of activin beta A- and beta B-subunit and follistatin messenger ribonucleic acids suggests multiple sites of action for the activin-follistatin system during human development. Journal of Clinical Endocrinology and Metabolism 78 1521-1524.

Ueno N, Ling N, Ying SY, Esch F, Shimasaki S \& Guillemin R 1987 Isolation and partial characterization of follistatin: a single-chain Mr 35000 monomeric protein that inhibits the release of follicle-stimulating hormone. PNAS 84 8282-8286.

Vanttinen T, Kuulasmaa T, Liu J \& Voutilainen R 2002 Expression of activin/inhibin receptor and binding protein genes and regulation of activin/inhibin peptide secretion in human adrenocortical cells. Journal of Clinical Endocrinology and Metabolism 87 4257-4263.

Wakatsuki M, Shintani Y, Abe M, Liu ZH, Shitsukawa K \& Saito S 1996 Immunoradiometric assay for follistatin: serum immunoreactive follistatin levels in normal adults and pregnant women. Journal of Clinical Endocrinology and Metabolism 81 630-634.

Wang QF, Khoury RH, Smith PC, McConnell DS, Padmanahban V, Midgley AR Jr, Schneyer AL, Crowley WF Jr \& Sluss PM 1996 A two-site monoclonal antibody immunoradiometric assay for human follistatin: secretion by a human ovarian teratocarcinoma-derived cell line (PA-1). Journal of Clinical Endocrinology and Metabolism 81 1434-1441.

Wang EY, Woodruff TK \& Moawad A 2002 Follistatin-free activin A is not associated with preterm birth. American Journal of Obstetrics and Gynecology 186 464-469.

Wankell M, Werner S \& Alzheimer C 2003 The roles of activin in cytoprotection and tissue repair. Annals of the New York Academy of Sciences 995 48-58.

Woodruff TK, Sluss P, Wang E, Janssen I \& Mersol-Barg MS 1997 Activin A and follistatin are dynamically regulated during human pregnancy. Journal of Endocrinology 152 167-174.

Yokoyama Y, Nakamura T, Nakamura R, Irahara M, Aono T \& Sugino H 1995 Identification of activins and follistatin proteins in human follicular fluid and placenta. Journal of Clinical Endocrinology and Metabolism 80 915-921.

Received 7 May 2007

First decision 19 June 2007

Revised manuscript received 15 August 2007

Accepted 24 August 2007 